\title{
Narratives of Trauma and Loss in Caryl Phillips's Crossing the River and A Distant Shore
}

\section{Nick Bentley}

\section{(2) OpenEdition \\ 1 Journals}

Electronic version

URL: https://journals.openedition.org/ces/4448

DOI: $10.4000 /$ ces.4448

ISSN: 2534-6695

Publisher

SEPC (Société d'études des pays du Commonwealth)

\section{Printed version}

Date of publication: 1 September 2017

Number of pages: 21-31

ISSN: 2270-0633

\section{Electronic reference}

Nick Bentley, "Narratives of Trauma and Loss in Caryl Phillips's Crossing the River and A Distant Shore", Commonwealth Essays and Studies [Online], 40.1 | 2017, Online since 02 April 2021, connection on 24 January 2022. URL: http://journals.openedition.org/ces/4448 ; DOI: https://doi.org/10.4000/ces.4448

\section{(c) (†) $\odot$}

Commonwealth Essays and Studies is licensed under a Licence Creative Commons Attribution - Pas d'Utilisation Commerciale - Pas de Modification 4.0 International. 


\section{Narratives of Trauma and Loss in Caryl Phillips's Crossing the River and A Distant Shore}

This article argues that trauma is at the heart of Caryl Phillips's fiction with particular reference to two novels, Crossing the River (1993) and A Distant Shore (2003). It assesses a number of writers associated with trauma theory and takes issue with the prevailing idea that trauma studies do not sit well with postcolonial literary practice. Close readings of the two novels reveal how their focus on trauma allows Phillips to articulate narratives that reveal postand neo-colonial contexts.

Caryl Phillips's fiction is distinctive in its exploration of migrant identities and narratives of cultural translation and exchange across a broad range of historical and geographical contexts. The Final Passage (1985), for example, examines the experiences of the Windrush generation of immigrants to Britain; Cambridge (1991) presents differing perspectives on plantation slavery in the early nineteenth century in the West Indies and Britain; The Nature of Blood (1997) ranges across several periods and locations including Renaissance Venice, Germany in the 1930s and 40s, and a fifteenth-century diaspora of Jewish people from Germany to Venice; and Dancing in the Dark (2005) addresses issues of racism and performed black identities in the popular theatre world of early twentieth-century New York. Phillips's experimentation with narrative form also stresses the communication of voices across borders, historical periods, genres, and modes of writing. His fiction tends to use first-person narratives, whose characters often reveal their traumatic experiences as both victims and implied perpetrators of slavery, racism, war, and violence, often resulting in psychological instability. ${ }^{1}$ In this article, I argue that what lies at the centre of Phillips's writing is the articulation of individual and shared experience of trauma as a consequence of (post)colonial systems of exploitation with especial reference to two novels: Crossing the River (1993) and A Distant Shore (2003). For Phillips, trauma affects the perpetrators and the victims of exploitative colonial and postcolonial power relationships in differing ways, but they are all bound up with the economic frameworks embedded in colonial, postcolonial and neo-colonial relationships. Crossing the River comprises four narratives, one set mainly in Liberia in the nineteenth century; one recounting the experiences of a runaway slave in nineteenthcentury America; a third providing the ship captain's log of an eighteenth-century slave trading ship; and one told from the perspective of a white British woman who has an affair with a black American GI during the Second World War. These narratives are framed by a voice that traverses historical and geographical moments in order to reflect an African diaspora driven by the slave trade as well as articulating the experiences of characters who are implicated in the exploitative systems of slavery. A Distant Shore juxtaposes the narratives of two main characters whose experiences have forced them to move into new areas and new hostile communities: one fleeing civil war in Africa, and the other relocating to a new area of a northern English town after experiencing

1. Phillips has commented that first-person confessional narratives reveal "a deep desire to speak, a deep necessity to communicate, which is born out of a hurt, a displacement, a sense of exclusion" (Clingman 136). 
traumatic incidents. Alongside these narratives of personal trauma I discuss the way in which the novel develops these experiences into broader national, cultural and historical narratives.

Before discussing the fiction it is necessary to address the place of trauma theory with respect to the (post)colonial contexts of Phillips's work. There has, of course, been much critical discussion of the appropriateness of trauma theory to postcolonial literary studies. The emergence of trauma studies in the work of the Yale School of deconstructionist and textualist theories in the 1990s, led by Cathy Caruth in particular, was marked by its grounding in Freudian psychoanalysis which, despite taking account of historical contexts, offered a problematic set of emotional and psychological relationships with the past which was at odds with the historicized and materialist tenor of most forms of postcolonialism. ${ }^{2}$ Trauma for Freud is bound up with core concepts of neuroses related to memory, melancholia and the repetition-compulsion drives that, in their rejection of a temporal linearity, effectively disrupt a materialist model of historical context. In addition, the difficulty of the trauma sufferer in articulating the direct experience of the originating traumatic event is at the core of the Freudian approach developed by Caruth in the early 1990s. This "unspeakability" is clearly at odds with postcolonialism's imperative to reveal and disclose formerly hidden histories of marginalization and exploitation, perhaps no more so than in the history of slavery that forms a crucial aspect of much (post)colonial history and is so central to Phillips's novel Crossing the River. A number of critics have challenged Caruth's position, for example Dominic LaCapra (2004), who is critical of its overly broad definition of trauma and its inability to distinguish between absence and loss. Stef Craps has noted that despite Caruth's claim that the study of trauma has the possibility to "contribute to crosscultural solidarity and to the creation of new forms of community" (156), much of the work produced under the banner of trauma studies from the 1990s onwards has tended to privilege western examples in the guise of a universalizing model. As Craps rightly notes: "For trauma studies to have any hope of redeeming its promise of ethical effectiveness, traumatic metropolitan or First-World histories must be seen to be tied up with histories of colonial trauma" (156). Michael Rothberg (2008) also identifies the need for a decolonized approach to trauma studies that extends beyond the tendency to focus on European and US-American histories. Similarly, Irene Visser has offered a thorough account of the debate, identifying some of the key problems in the relationship between trauma studies and postcolonialism, and concludes that:

A more comprehensive conceptualization of trauma is needed to theorize collective, prolonged, and cumulative experiences of traumatization. [...] In this respect, trauma theory's foundation in Freudian psychoanalysis may be acknowledged as a point of departure that invites further expansion [...] to enable an openness towards non-western, non-Eurocentric models of psychic disorder and of reception and reading processes. (280)

Published in 2011, this is an accurate description of the state of play in the critical response to the relationship between trauma studies and postcolonialism. However, a number of recent critics have identified ways in which Caruth's initiating research can be used to fulfil a specifically postcolonial approach to trauma studies. Norman Saadi 
Nikro (2014), for example, argues that postcolonial critics may have been too hasty in dismissing the model established by Caruth and goes on to identify other developments in trauma theory that are more conducive to a positive engagement with postcolonial studies, including those developed by Laura Brown (1995), Samuel Durrant (2012) and Anne Whitehead (2004). In this article, I argue that Phillips's work offers just such a way of presenting trauma narratives that contribute to postcolonial studies. As we shall see, Phillips's writing draws on psychoanalytic models and resonates with much of the work Caruth and others develop with respect to trauma narratives, but it does so in order to enhance a committed and historicized account of slavery that encourages collective memorization. As several critics have noted, for example Boutros (2012), Courtman (2012), Craps (2012), and Di Maio (2012), articulating trauma narratives represents, for Phillips, a way of preserving the memories of exploitation, guilt and racism that continue to resonate in contemporary western societies.

However, the means by which trauma - a concept that resists concrete representation and expression - can be articulated in literary fiction is problematic. As Paul Crosthwaite has noted: "Trauma, as a paradigm of the historical event, possesses an absolute materiality, and yet, as inevitably missed or incompletely experienced, remains absent and inaccessible" (1). In terms of the theories of trauma fiction, the relationship between psychological and physical experience and the literary expression of trauma has been interrogated by a number of critics. Some have made the case that trauma fiction is a way of attempting to articulate experiences that by their very nature resist material expression. Anne Whitehead for example, begins her book, Trauma Fiction, by highlighting the fact that " $\mathrm{t}]$ he term 'trauma fiction' represents a paradox or contradiction: if trauma comprises an event or experience which overwhelms the individual and resists language or representation, how can it be narrativised in fiction?" (3) However, her book argues - by reference to a number of British novels of the contemporary period including Pat Barker's Another World (1998), Jackie Kay's Trumpet (1998) and Phillips's The Nature of Blood (1997) - that fiction can articulate trauma through the deployment of specific literary forms and techniques. These techniques often eschew linear plotting and rationalized expressions of cause and effect and lend themselves to similar approaches in postmodernist and some postcolonial literature. ${ }^{3}$ Laura Vickroy is also interested in the way in which narrative techniques can be used by authors to reflect, formally, the experience of trauma. As she argues: "stylistic innovations have reflected our understanding of consciousness as well as our capacity to imagine the human psyche in all its facets, and have proved effective in approximating for readers the psychic defenses that pose obstacles to narrating and recovering from trauma" (ix). Many critics have sought to examine the ways in which narrative form and style have been used to convey the experience of trauma and, as Vickroy notes, there is some overlap with narrative techniques that have been associated with modernism and postmodernism such as fractured narratives; the use of multiple points of view; experimentation with the presentation of time in terms of repetition and the disruption of linear narrative; and the development of characterization that suggests fragmented, split or multiple identities. As we shall see, many of these literary techniques are deployed in Crossing the River

3. Paul Crosthwaite (2009), in particular, has identified the link between post Second World War trauma narratives and postmodern narrative techniques. 
and $A$ Distant Shore as a means by which Phillips conveys the experience of a variety of (post)colonial traumas.

\section{Crossing the River}

Crossing the River opens with the account of a father who, due to his desperate economic situation, is forced to sell his daughter and two sons into slavery. This moment of trauma that implicates the father as both originator and victim is accompanied by the following image: "To a father consumed with guilt. You are beyond. Broken-off, like limbs from a tree" (2). This anthropomorphic image of the damaged tree recalls the figure of Tancred in Torquato Tasso's Gerusalemme Liberata who, some time after inadvertently killing his love Clorinda, lops off the branches of a tree from whose stumps blood gushes while simultaneously emitting the revenant cries of his murdered lover. This is a myth that Freud refers to in Beyond the Pleasure Principle as an example of the repetition-compulsion propensity of people who "suffer again and again in an endless repetition of the same fate" (60). It is also a passage that is taken up by Caruth, who develops Freud's analysis in the following terms:

For what seems to me particularly striking in the example of Tasso is not just the unconscious act of the infliction of the injury and its inadvertent and unwished-for repetition, but the moving and sorrowful voice that cries out, a voice that is paradoxically released through the wound. Tancred does not only repeat his act but, in repeating it, he for the first time hears a voice that cries out to him to see what he has done. The voice of his beloved addresses him and, in this address, bears witness to the past he has unwittingly repeated. Tancred's story thus represents traumatic experience not only as the enigma of a human agent's repeated and unknowing acts but also as the enigma of the otherness of a human voice that cries out from a wound, a voice that witnesses the truth that Tancred himself cannot fully know. (2-3)

Caruth identifies this simultaneous and paradoxical knowing and unknowing as the "crucial link between literature and [trauma] theory" before going on to describe the "double wound" that underpins trauma narratives. In this context, the relationship between the originating traumatic experience and its reappearance locks sufferers in a repetitive cycle that disallows forward movement and that places them "between the story of the unbearable nature of an event and the story of the unbearable nature of its survival" (7). Caruth's model of trauma suggests a repeated revisiting of the originating moment of trauma and, although this aspect of her theory has attracted criticism, as noted above, elements of this model resonate in the repetitious patterning of Crossing the River.

This is registered particularly by Phillips in the repeated use of the phrase - "The crops failed. I sold my children" - at the opening and closing of the first section of the novel and then again in the final section. The emphasis of this repeated phrase performs a double move: it both enunciates the guilty act, and simultaneously offers a justification for it based on the desperate economic situation in which the father finds himself. The father implicates the reader in the dilemma he is facing by suggesting that the trauma is grounded in a collective wound that links past and present. The first time the phrase appears it is followed by "I remember," thus reinforcing the reoccurrence of the trauma in the sufferer's mind (1). However, this "remember" is also directed out to an implicated audience and, like the ghost of Hamlet's father, is delivered by one who has slipped out of time and who travels across various contexts in which the legacies of 
slavery and (post)colonial exploitation are repeated. As the disembodied voice tells us: "the chorus of a common memory began to haunt me. For two hundred and fifty years I have listened to the many-tongued chorus." This is accompanied by a gesture that resides ambiguously between testimony and revenge: "For two hundred and fifty years I have waited patiently for the wind to rise on the far bank of the river. For the drum to pound across the water. For the chorus to swell" (2). Here, the invocation of the chorus moves the memory from the individual to the collective; the singular instance of colonial injustice is thus sutured to a shared narrative of trauma that is invoked to grow louder.

This transfer of a transgenerational trauma affecting both perpetrator and victim to an implicated audience frames the other instances of trauma represented in the various histories and narratives found in the novel. There are a number of moments that can be described as traumatic in Crossing the River and which compulsively repeat this originating moment of violence, driven by the mechanisms of imperial economic power. The first main section of the novel, "The Pagan Coast," describes the relationship between Edward Williams, a progressive plantation owner who has inherited a number of slaves, and whose Christian beliefs have led him to question his moral position as an agent within the economic framework of slavery, and Nash Williams, who has been born into slavery (taking his owner's surname) but has been educated and eventually freed. As a freed slave, Nash is encouraged by his former owner to move to Liberia, in order to carve out an independent existence as well as to disseminate the Christian message in Western Africa. Nash's experiences are communicated in a series of letters to Edward; however, it becomes increasingly apparent that this correspondence has not been received, leading Nash to believe that he has been abandoned by his former master and surrogate father. This estrangement results in a form of traumatic break that resonates differently for each character and represents the development of a nuanced trauma narrative that sits in contrast to the more direct experiences of trauma suffered by other characters in the novel. One example of an immediate experience of trauma is the account of the old runaway slave Martha Randolph's experiences of travelling west across America in an attempt to find a better life. While on her journey she remembers several past traumatic experiences such as the loss of her husband and daughter at a slave auction. Fatim Boutros (2012) has rightly focused on this part of the text as an important echo of experiences recounted in slave narratives, but the novel also stresses that (post)colonial trauma can take multiple forms that cut across the usual divisions between colonial perpetrator and colonized subject. "The Pagan Coast" section reveals something of the complex forms of trauma explored in the novel. The second half of this part is reminiscent of Conrad's Heart of Darkness in that it recounts Edward's trip to Liberia and his discovery that Nash has moved into the interior of the country and rejected his earlier religious and cultural beliefs, a set of western ideologies that are registered as inappropriate and inadequate in the "heart" of Africa.

There are a number of key episodes in this narrative that can be described as traumatic. For Nash, the shock of his perceived abandonment by Edward articulates itself in the form of a crisis of religion and consequently of cultural and national identity. As Nash recounts in his final letter: "The truth is, our religion, in its purest and least diluted form, can never take root in this country [...]. It has taken my dark mind many years to absorb this knowledge" (62). However, this experience has resulted in Nash being able 
finally to step forward as a free man, released from the ideological shackles of an imposed colonial religion, suggesting that trauma represented by a ruptured former identity can eventually be overcome: "I must suspend my faith and I therefore freely choose to live the life of an African" (62). This decision is extended to the personal relationship between the former slave and his owner: "That my faith in you is broken, is evident. You, my father, did sow the seed, and it sprouted forth with vigour, but for many years now there has been nobody to tend it, and being abandoned it has withered away and died" (63). This clearly establishes the relationship between the two as extended beyond economic and legal contexts to one of moral responsibility that can be described as a post-slavery relationship.

In response to this situation, the experience of trauma in Edward's story is two-fold; firstly, when he hears of Nash's death, and secondly, when he discovers that his surrogate son has renounced both his former religion and all ties to his erstwhile father. The news of Nash's death causes a reaction in Edward that resembles traumatic experience in that it is marked by physical reaction and mental incomprehension: "Edward spent the remainder of the day, and the full length of the night, sitting upright in the chair, his anguished mind questioning in every conceivable direction, but forever stumbling into blind alleyways which proved to be swept clean of any meaning" (58). This represents a moment of traumatic crisis for Edward, whose disconnection with his surrogate son strikes at the root of all his previous ideological and spiritual understanding concerning his relationship to slavery. The philanthropic, yet privileged, attitude he has negotiated for himself within the system of slavery is at this stage beginning to fall away. The sense of trauma resonating through the slave system as a whole (and reiterated in Phillips's multiple narratives) returns to Edward at this moment not as a justification of his actions but as a marker of his implication in the immoral system. As Tancred hears the screams of the lover he has murdered, Edward is similarly catapulted into an existential crisis by recognizing his own culpability in Nash's demise. This experience leaves him floundering, with his previous recourse to Christianity left inadequate and silent in the face of the enormity of the system he has tried to circumvent; when arriving at Nash's settlement he attempts to offer a prayer through song, but this action is shown to be hollow: "The natives stared at him, and watched as the white man's lips formed the words, but no sound was heard. Still, Edward continued to sing his hymn. [...] [T] heir hearts began to swell with the pity that one feels for a fellow who has lost both his way and his sense of purpose. This strange old white man" (69-70). In this reversal of fortunes, Edward now stands as the marginalized other, subject to a positional inferiority warranting pity from the rooted west Africans.

Although the trauma for Edward remains unspeakable, it is conveyed effectively by Phillips's control of the narrative and this section is followed by three further narratives that contextualize the effects and causes of slavery; a series of narrations that combine to convey the sense that the traumatic rupture in humanity represented by slavery exceeds its eighteenth and nineteenth-century context. ${ }^{4}$ The implication is that slavery as a system is so pernicious that its effects exceed the moment of its ending. The very last section of the novel reinforces this point by connecting the narratives set in the nineteenth century with more modern examples of an exploitative system that is

4. The concept of transgenerational trauma associated with slavery and/or colonialism has been identified by a number of critics including Joy DeGruy (2005) and Gabriele Schwab (2010). 
registered along racial inequalities. Formally, this section acts as a kind of repetition of a traumatic memory in its refusal to allow the slave trade to be designated as a crime of the past. The novel's manipulation of historical cause and effect thus reintroduces the guilt firmly into the neo-liberal and neo-colonial present and the social structures of late capitalism are read as grounded in the exploitative systems that drove slavery: "The slave who mounted this block is now dying young from copping a fix on some rusty needle in an Oakland project" (236). Contemporary narratives of economic struggle and exploitation are thus read as intimately connected to the past. Through the perspective of the slave father who "sold my beloved children" in the nineteenth century the voice slips out of time and connection is made to "a helplessly addicted mother" in Brooklyn, and "a barefoot boy in Sao Paulo" (235). In another reference, "A mother watches. Her eleven-year old daughter is preparing herself for yet another night of premature prostitution" (235-6). In its connection of desperate but implicated parent and exploited child this contemporary situation echoes the originating repetition of the first chapter: "The crops failed. I sold my children."

The text, then, gathers individual memories into a collective expression of trauma that is repeated across time for both victim and perpetrator with the implication that the specific forms of slavery that emerged in the eighteenth and nineteenth centuries represent a traumatic rupture in western history that continues to be remembered in the present. This aspect of testament is the residing power of Phillips's Crossing the River, despite the attempt to strike a positive note in the novel's ending that suggests the children "arrive on the far bank of the river" (237).

\section{A Distant Shore}

A positive conclusion is something that is not available in Phillips's 2003 novel $A$ Distant Shore, the title of which echoes the previous novel and which also develops a transnational narrative of ethnic conflict and racism, although this time located more firmly in the contemporary moment. A Distant Shore includes narratives in which the loss of loved ones in terms of death, divorce and exile is a prominent feature; however, it is in the incapacity of the characters to come to terms with their losses, or indeed with the accumulation of loss that results in psychosis. The relationship between loss and trauma is thus at the heart of Phillips's examination of personal and collective identities.

The novel details the personal experiences of two characters who form what might seem to be an unlikely friendship: Dorothy Jones, a late-middle-aged, retired music teacher; and Gabriel, who is fleeing a brutal civil war in Africa and after arriving as a refugee in Britain, ends up living in the same northern English village as Dorothy. Gabriel changes his name to Solomon when he moves to the village and it is with that name that we first encounter him. Although he successfully flees tribal and sectarian violence in the African state, it is with something of a dark irony that he is eventually killed by a group of white British youths who subject him to an unprovoked racist attack. Gabriel's experiences in the war are clearly a source for trauma, but we learn that Dorothy too has undergone a series of recent traumatic experiences in that she has lost both her parents, been divorced from her unfaithful husband, retired from her job, and lost her younger sister to cancer. In this section of the article, I develop the discussion of trauma presented in the previous section in relation to Crossing the River to argue that the personal experiences suffered by Dorothy and Gabriel are mapped onto broader 
collective narratives of postcolonial trauma. These collective trauma narratives relate to three contexts, two of which have long historical trajectories and one of which is more recent. Firstly, Britain's decline in world power in the postwar period, associated in part with the loss of empire, can be seen as a source of collective trauma resulting in the fragility of British (and in particular English) identity (as Gilroy [2006] and Crosthwaite [2007] have identified). Secondly, a related sense of trauma associated with the decline of key industries in Britain in the period from the mid-1980s onwards, which is felt especially keenly in the northern English location in which much of the action takes place. Thirdly, the civil war in the fictionalized African state (based on Rwanda) that is central to Gabriel's narrative. Before moving on to the collective traumas, however, it is useful to frame the context and details of the individual traumas in the novel.

The novel begins: "England has changed. These days it's difficult to tell who's from around here and who's not. Who belongs and who's a stranger. It doesn't feel right" (1). This introduces a theme of the novel that represents a nation that is unsure and fearful of outsiders. The reference to bodily and psychological responses to the changed atmosphere - "it doesn't feel right" - suggests a kind of collective emotional response that points to a certain traumatic break. I will return to the context for this regionalized collective trauma, but it should be stressed that the sentiment is presented through the voice of Dorothy Jones, whose recent experiences have given rise to concerns with her mental health. Dorothy is seeing a psychiatrist because she refuses to accept the death of her sister and several incidents related in the novel lead the reader to question the reliability of her reading of situations, other characters and recent events. Nevertheless, the linking of the personal and subjective to the collective and national is foregrounded by the placing of these observations at the opening of the novel (at a moment when the reader would not yet question the validity of the sentiments presented).

Dorothy has moved to a new housing estate called Stoneleigh on the edge of a traditional northern working-class town and her trauma is presented in terms of what the reader is invited to infer from her first-person narrative. For example, she is accused of behaving strangely when giving private piano lessons to a local teenage girl named Carla. Although Dorothy's narrative foregrounds the offence she takes at the accusation, it is implied that Carla and her mother's complaint about Dorothy's behaviour is legitimate and the novel gradually reveals a series of increasingly eccentric incidents involving the retired teacher. Trauma in Dorothy's case is revealed in terms of the repression of events that are too painful to accommodate in her consciousness. The mental wound inflicted by the death of her sister, Sheila, remains open and in fact Dorothy fails to accept that her sister has died. Her friendship with Solomon develops in part because he is able to identify that she is suffering from some form of traumatic pain and it is suggested that it is because of his own traumatic experiences that he is able to empathize with her situation. As he tells her at one point: "It is true that sometimes life can be difficult, yes?" (32), and later, "But it is not good to keep these things locked up inside" (33). Solomon becomes a kind of informal psychoanalyst for Dorothy and she gradually begins to realize the importance of their developing friendship: "I am simply happy to be in Solomon's company" (35). It is not until later in Dorothy's narrative, however, that an earlier repressed memory is shown to be at the root of her denial of Sheila's death. When Dorothy takes a trip to the coast, she remembers her sister informing her (when they were in their early twenties) that their father had sexually abused Sheila, and it is at 
this release of the repressed memory that Dorothy is able to accept her sister's death, although her feelings towards her father remain ambiguous.

If Solomon serves as a surrogate psychoanalyst for Dorothy, then the older woman acts as a surrogate mother for the younger refugee, revealing one of the main causes for his traumatic experiences. While in Africa, Gabriel witnessed the brutal killing of his parents and the rape and murder of his two younger sisters by soldiers. During the attack, which has been instigated because of his involvement in the civil war, Gabriel is secreted in a cupboard and watches the killings unseen. But perhaps the height of this traumatic experience is the fact that when the soldiers leave, although Gabriel's mother is still alive, he flees the house because he "dare not stay with her too long" (85). The trauma induced by this experience continues to haunt Gabriel. When he later arrives at his uncle's house we are told "the pain of what he has witnessed begins to rise through his body" (87), revealing classic symptoms of PTSD, and much later, when he is held in a detention centre in Britain, the root cause of the trauma returns to him in dreams: "He hears her voice, but she does not turn around to face him. He reaches down and pulls back her shoulder that he might look into her eyes, but there is no face. It is as if somebody has taken a piece of cloth and rubbed out her features" (132). As with Tancred and Clorinda, Gabriel's trauma is a complex mix of guilt and shock at being witness to, and implicated in, horrific actions. By taking part in the civil war and by abandoning his mother, father and sisters, he is implicated in their deaths and his trauma thus haunts him as both the victim and perpetrator of violence. It is in this context that Gabriel, now called Solomon, is able to connect with Dorothy as both a fellow sufferer of trauma, and as a potential source of alleviation of his sense of guilt. Indeed, unlike the situation involving his real mother, his relationship with Dorothy offers him an opportunity to help.

Overlaid on these individual narratives are traumas associated with collective identities. The middle sections of the novel detail the way in which the civil war in the African state (based loosely on Rwanda) represents a wound in the collective psyche of the nation. But it is also in the sections that are set in the north of England that another collective trauma manifest in terms of an insular and xenophobic suspicion of outsiders is revealed. Dorothy's dead father represents this outlook; as she notes "I'm glad that Dad isn't here to see what's become of his town" (13) and later reminisces "He'd be there sucking on his pipe and bemoaning the fact that we were giving up our English birthright and getting lost in a United States of Europe" (27). But Dorothy is also able to reflect on possible causes for this reaction in terms of the collective trauma visited on the north of England by the set of economic policies that came to a head in the Thatcher period: the closure of the mines and the decline in the heavy industries that were the bedrock of towns like Weston. In this context Dorothy, as a conservative teacher, is regarded as representative of the middle-class metropolitan elite who are seen as one of the causes of the area's industrial decline; when discussing the attitudes of a man who lives in Weston to the newly arrived population of Stoneleigh she speculates:

I'm sure he sits at home at the bottom of the hill [...] and considers me and everyone else in the new development to be interlopers. All of us, disturbing a pattern that has gone on for decade after decade until Stoneleigh came along to make them feel as though their shrinking lives, which were already blighted by closures and unemployment, were even less important than they had hitherto imagined. (29) 
Behind this specifically regional collective experience is another narrative of decline, the source for another kind of collective wound, that of the decline of Britain as a world power in the postwar period. As Paul Gilroy (There Ain't no Black, Postcolonial Melancholia) has noted, immigration all too often becomes the innocent target of populist political rhetoric around the causes of this decline, revealing a form of "postcolonial melancholia." In Phillips's novel, Solomon is attacked and killed by a gang of British youths whose employment prospects look bleak and for whom industrial and national decline has produced a collective anger that manifests itself in arbitrary acts of violence against outsiders. The end that befalls Solomon/Gabriel at the hands of white, working-class, northern English youths after he has escaped the violent civil war in Africa paints a depressing picture of a world that is entangled in a cycle of violence, trauma, loss and revenge. In this sense, the circulation of traumatic violence reflects a set of neo-liberal and globalized economic frameworks that show connections across locations, individuals and communities.

To conclude, both Crossing the River and A Distant Shore reveal Phillips's interest in trauma as a source for narrative engagement and examination of ideological and political discourses, both historically and pertaining to the present. Indeed, the very capacity of traumatic narratives to slip free of conventional time and linear structures allows for a trans-historical, trans-national and trans-generational set of connections. His fiction shows a sophisticated understanding of the ways in which trauma narratives can identify aspects of the unspeakable for the individual that can be re-articulated as powerful commentaries on collective acts of violence and economic exploitation. In addition, his work represents that call from critics such as Craps, Rothberg and Visser for a fertile conjoining of trauma narratives with postcolonial literature that challenges the argument that trauma theory has too often been located as an ahistorical and westerncentric set of theories.

Nick BentLEY Keele University

\section{Works Cited}

Barker, Pat. Another World. London: Viking, 1998.

Brown, Laura. "Not Outside the Range: One Feminist Perspective on Psychic Trauma." Trauma: Explorations in Memory. Ed. Cathy Caruth. Baltimore: Johns Hopkins UP, 1995. 100-12.

Boutros, Fatim. "Bidirectional Revision: The Connection between Past and Present in Caryl Phillips's Crossing the River." Caryl Phillips: Writing in the Key of Life. Ed. Bénédicte Ledent and Daria Tunca. Amsterdam: Rodopi, 2012. 175-90.

Caruth, Cathy. Unclaimed Experience: Trauma, Narrative, and History. Baltimore: Johns Hopkins UP, 1996.

Clingman, Stephen. "Other Voices: An Interview with Caryl Phillips." Salmagundi 143 (2004): 112-40.

Courtman, Sandra, "Dorothy's Heart of Darkness - How Europe Meets Africa in A Distant Shore." Caryl Phillips: Writing in the Key of Life. Ed. Bénédicte Ledent and Daria Tunca. Amsterdam: Rodopi, 2012. 265-82.

Crosthwaite, Paul. Trauma, Postmodernism, and the Aftermath of World War II. Basingstoke: Palgrave, 2009.

CRAPS, Stef, "Linking Legacies of Loss: Traumatic Histories and Cross-Cultural Empathy in Caryl Phillips's Higher Ground and The Nature of Blood." Caryl Phillips: Writing in the Key of Life. Ed. Bénédicte Ledent and Daria Tunca. Amsterdam: Rodopi, 2012. 155-73.

Di MAIO, Alessandra. "A New World Tribe in Caryl Phillips's A Distant Shore." Caryl Pbillips: Writing in the Key of Life. Ed. Bénédicte Ledent and Daria Tunca. Amsterdam: Rodopi, 2012. 249-64. 
De Gruy, Joy. Post Traumatic Slave Syndrome: America's Legacy of Enduring Injury and Healing. Portland, OR: Uptone Press, 2005.

Durrant, Samuel. "Surviving Time: Trauma, Tragedy, and the Postcolonial Novel." Journal of Literature and Trauma Studies 1:1 (2012): 95-117.

Freud, Sigmund. "Beyond the Pleasure Principle." 1920. Beyond the Pleasure Principle and Other Writings. Trans. John Reddick. London: Penguin, 2003. 43-102.

Gilroy, Paul. There Ain't No Black in the Union Jack: The Cultural Politics of Race and Nation. London: Hutchison, 1987.

—. Postcolonial Melancholia. New York: Columbia University Press 2006.

KaY, Jackie. Trumpet. London: Picador, 1998.

LACAPRA, Dominick. History in Transit: Experience, Identity, Critical Theory. Ithaca: Cornell UP, 2004.

Nikro, Norman Saadi. "Situating Postcolonial Trauma Studies.” Postcolonial Text 9:2 (2014): 1-21.

Philuips, Caryl. The Final Passage. London: Faber and Faber, 1985.

-. Cambridge. London: Bloomsbury, 1991.

- A Distant Shore. 2003. London: Vintage, 2004.

-. Crossing the River. 1993. London: Vintage, 2006.

- The Nature of Blood. 1997. London: Vintage, 2008.

—. Dancing in the Dark. 2005. London: Vintage, 2010.

RothberG, Michael. "Decolonizing Trauma Studies: A Response." Studies in the Novel 40:1-2 (2008): 224-34.

SCHWAB, Gabriele. Haunting Legacies: Violent Histories and Transgenerational Trauma. New York: Columbia UP, 2010.

VickroY, Laura. Trauma and Survival in Contemporary Fiction. Charlottesville: U of Virginia P, 2002.

VISSER, Irene. "Trauma Theory and Postcolonial Literary Studies." Journal of Postcolonial Writing 43:3 (2011): 270-82.

WhiteHEAD, Anne. Trauma Fiction. Edinburgh: Edinburgh UP, 2004. 